\title{
Freezing at the grounding line in East Antarctica: possible implications for sediment export efficiency
}

\author{
R. Souchez, ${ }^{1}$ A. Khazendar, ${ }^{1}$ D. Ronveaux, ${ }^{2}$ J.-L. Tison ${ }^{1}$ \\ ${ }^{1}$ Département des Sciences de la Terre et de l'Environnement, Faculté des Sciences, Université de Bruxelles, B-1050 Brussels, Belgium \\ ${ }^{2}$ Department of Geography, Temple University, Philadelphia, PA 19122, U.S.A.
}

\begin{abstract}
A study of the $\delta \mathrm{D}$ and $\delta^{18} \mathrm{O}$ composition of ice formed at or near the grounding line was undertaken in Terra Nova Bay, East Antarctica. The results indicate that a double-diffusion mechanism is responsible for freezing at the grounding line in areas sheltered from the sub-ice cavity circulation. Freezing at the grounding line is unlikely to be prevalent today, but the situation may have been different in the past when the ice reached the outer limit of the continental shelf and there was no sub-ice cavity. The implications for sediment export in the polar oceans are explained.
\end{abstract}

\section{INTRODUCTION}

Ice-rafted debris from icebergs derives mostly from subglacial entrainment by glaciers or ice sheets. The ice-substratum interface is a place where particles can be incorporated into the glacier sole. The basal debris can then be carried by glacier flow and reach the ocean if the ice mass begins to float. In order for the debris to be preserved in the basal ice at the front of a floating glacier or of an ice shelf, it must not have been released at the grounding line. If the melting point is reached at the glacier base in the coastal region and if melting prevails at the grounding line, subglacial meltwater loaded with sediments discharges there into the sea. The probability of preservation of basal debris in the frontal zone greatly increases if freezing occurs at or near the grounding line.

This paper investigates conditions for freezing at the grounding line. It uses stable isotopes to give evidence that such a situation occurs in Terra Nova Bay, East Antarctica.

\section{PRESENT-DAY CONDITIONS AT GROUNDING LINES}

The grounding line is usually defined as a line across the glacier where it goes afloat. However, it can also be considered as the limit between grounded ice and floating ice. Therefore, a grounding line exists if the glacier goes afloat or becomes grounded again. With such an extended definition in mind, the grounding line is in fact a transition zone between a grounded glacier or ice sheet and a floating glacier or ice shelf where the ice repeatedly loses and regains contact with the subglacial bed before eventually floating. It is relevant to consider such a transition zone in a work focusing on possible phase changes.

Drillings through ice shelves show evidence of accretion of marine ice layers under ice of meteoric origin (Zotikov and others, 1980; Oerter and others, 1992). In the upper part of marine shelf ice from the Filchner-Ronne Ice Shelf, Oerter and others (1992) showed the existence of particle inclusions in conjunction with horizontal layering. The inclusions most probably result from scavenging during marine ice formation. However, the overwhelming absence of debris layers between meteoric ice and marine ice suggests the absence of adfreezing at the grounding line. In general, available evidence favors melting rather than freezing.

Today, the frontal zone of most of the medium-sized and small ice shelves in Antarctica is well upstream of the maximum extent of the ice during the Last Glacial Maximum (LGM). Since glacio-isostatic loading of the crust has resulted in a depression of the coastal zone upstream of the continental slope or since overdeepening by ice flows has occurred, a cavity usually exists between the ice shelf and the ocean floor. This sub-ice cavity is subject to a specific oceanic circulation (Jacobs and others, 1992). Surface sea water in front of the ice shelf plunges because its density increases by release of sea salts during sea-ice formation. This water, at depth (high-salinity shelf water; HSSW), is above its pressure-melting point since the freezing point of sea water is lower when pressure increases (Lewis and Perkin, 1986). Therefore, this water has at depth sensible heat to transfer to the base of the floating ice. Melting occurs and the less dense water so produced leaves the cavity as ice-shelf water (ISW). Hence, melting rather than freezing must prevail today at or near the grounding line. If marine ice forms, it is mainly by accretion of frazil-ice crystals generated in the supercooled ISW as it rises towards the surface. The absence of plunging waters is thus a prerequisite for possible freezing at the grounding line.

\section{EVIDENCE FOR FREEZING CLOSE TO GROUND- ING LINES IN TERRA NOVA BAY}

The Hells Gate Ice Shelf in Terra Nova Bay (Fig. 1) was studied in detail. Because of the action of katabatic winds, the ice surface is losing ice, mostly by sublimation. Since top-surface ablation is prevalent, an upward velocity component exists and the marine ice formed at the ice-shelfocean interface ultimately appears at the surface. Debrisrich ice is present under the moraine ridges which appear at the separation between different ice flows. The western moraine ridge is located along a flowline that connects with 

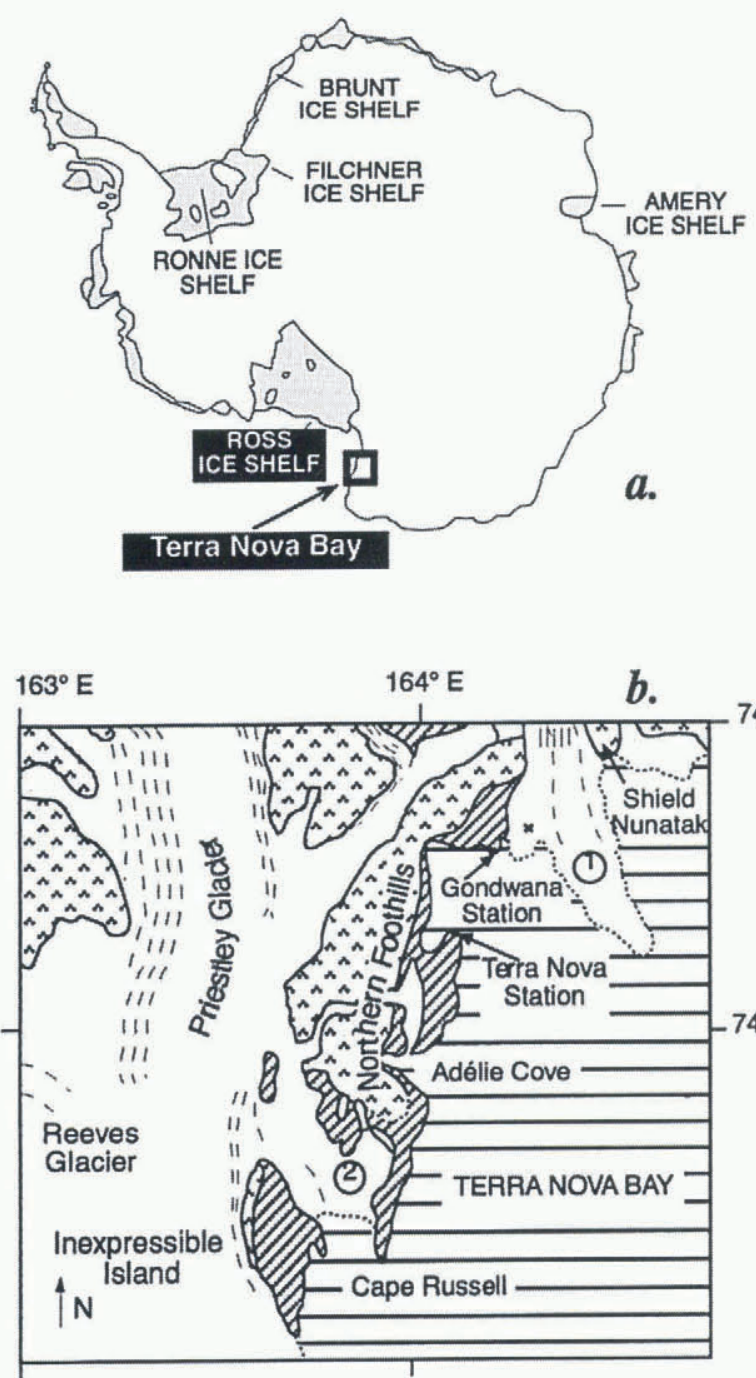

\section{c.}

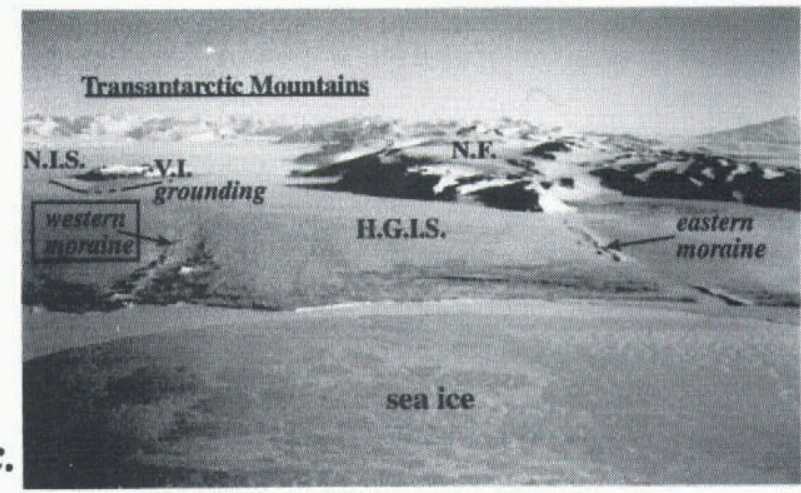

Campbell glacier tongue
(2) Hell's gate ICE SHelF
$\square$ Ross sea
B. Bedrock
iiil Ice fall

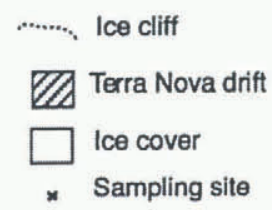

$74^{\circ} 33^{\prime} S$

$74^{\circ} 45^{\prime}$ s $d$.
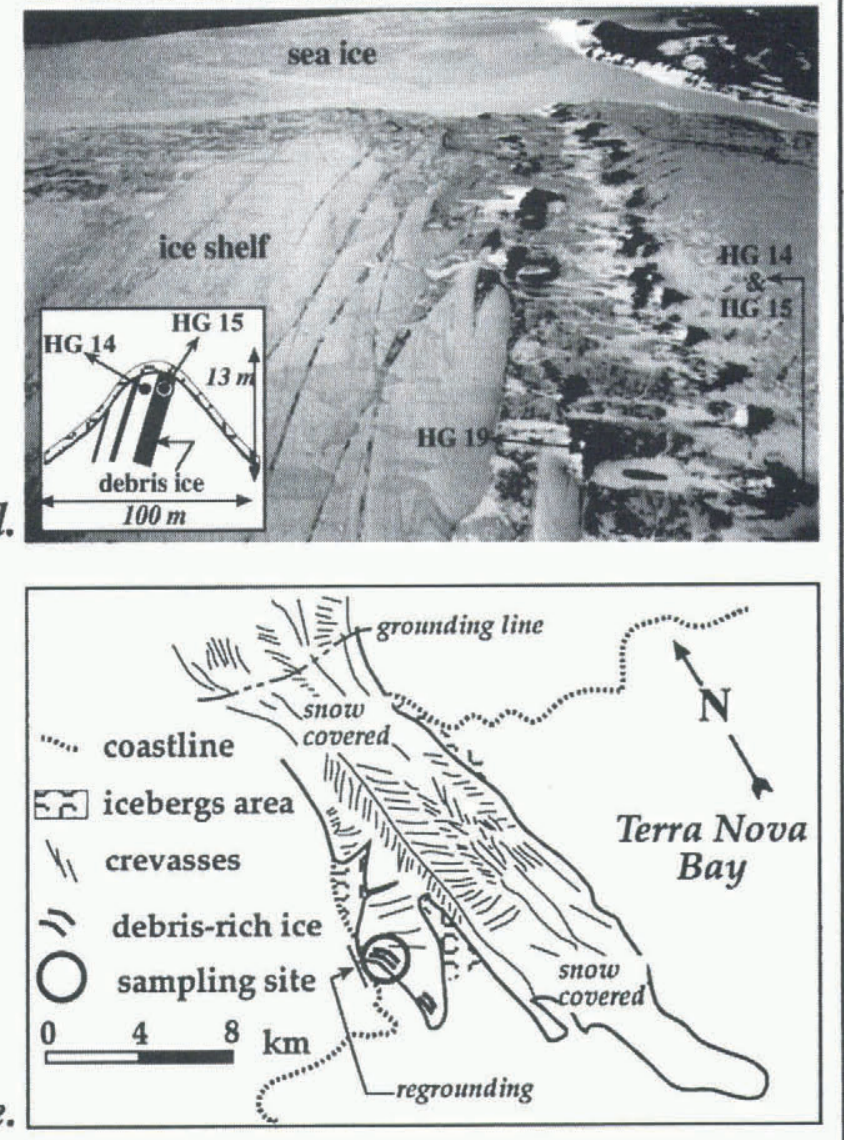

Fig. 1. Sampling sites in Terra Nova Bay area: $(a, b)$ general location; (c) oblique view of Hells Gate Ice Shelf ( HGIS) looking upstream; NIS, Nansen Ice Sheet; VI, Vegetation Island; NF, Northern Foothills; (d) closer view of the western moraine from HGIS looking downstream, with ice-core locations and detailed sketch for cores HG 14 and HG 15; (e) detailed sketch of Campbell Glacier Ice Tongue with sampling site.

Vegetation Island, a pinning point of the ice shelf. There is little doubt that the debris forming the ridge has been entrapped into the ice at the base. Like the marine ice, because of ablation, the debris appears at the surface and forms an ice-cored ridge.

A detailed investigation of the ice at the level of the western moraine ridge shows not only debris and clear-ice layers but also sponge remains in growth position and serpulid worm tubes. It is difficult to interpret the significance of the presence of these serpulid worm tubes since Adélie penguins, which are numerous in the area, are known to build small hillocks from them. As shown by photographs from a robotic submarine, sponges are growing near a grounding line (Powell and others, 1996). Sponge remains in growth position can be incorporated into the ice shelf because of anchor-ice formation on the sea floor. Dayton and others (1969) indicated that, in McMurdo Sound, anchor ice develops to about $33 \mathrm{~m}$ depth on the sea floor. When it becomes detached, because of inherent buoyancy, it floats to the undersurface of an ice cover, carrying with it portions of the substratum which can weigh at least $25 \mathrm{~kg}$. By this process, sponges can be incorporated into the ice shelf. Because of their location well upstream in the ablation zone of the Hells Gate Ice Shelf, these sponge remains must have been incorporated near the grounding line. The bottom water where the sponges were growing must not have been above the pressure-melting point in order for anchor ice to be formed. Therefore, the area where the sponges have grown must have been sheltered in some way from the influence of HSSWs, which would be above their freezing point at depth. 
Other evidence supporting the possibility that certain areas are sheltered from sub-ice cavity circulation can be inferred from temperature and salinity measurements made in front of the ice shelf (Tison and others, in press). Oceanic profiles down to $600 \mathrm{~m}$ depth show a transition between ISW and HSSW below $440 \mathrm{~m}$. However, typical high-salinity shelf waters were not observed in the profiles. This suggests that plunging of HSSW affects only a narrow central trough more than $700 \mathrm{~m}$ deep that exists beneath the ice shelf (Stocchino, 1991). Since a maximum ice thickness of about $200 \mathrm{~m}$ (personal communication from I. E. Tabacco, 1997) was observed immediately downstream of Vegetation Island, there must be sheltered sea-floor areas where anchor ice can develop away from the influence of HSSW.

Bathymetric information available (Stocchino, 1991) in the Campbell Glacier Ice Tongue area also suggests a sheltering effect where the debris-rich ice formed near the grounding line originated (Souchez and others, 1995).

\section{FREEZING BY A DOUBLE-DIFFUSION MECHAN- ISM AT THE GROUNDING LINE}

Zotikov (1986) discussed at length the various possible processes controlling the mass balance at the bottom of an ice shelf. Using the Amery Ice Shelf as a case-study, this author suggested heat transfer between a water layer of reduced salinity and sea water to explain the abnormally high freezing rates deduced from temperature profiles across the ice shelf. Lambert outlet glacier, at the bottom of which melting takes place because of enhanced ice thicknesses, is seen as a connection between the basin of subglacial runoff from the ice-sheet center and the sea. It provides the source for outflowing waters of reduced salinity under lithostatic load. A rough calculation assuming no mixing between the two water layers, salinity differences of about $20 \%$ and relative flow velocities of about $10 \mathrm{~cm} \mathrm{~s}^{-1}$ provided freezing rates of about $1 \mathrm{~m} \mathrm{a}^{-1}$, in accordance with the observed rates. This mechanism, however, requires the sea water to be at its local freezing point, which precludes areas under the influence of a sub-ice cavity circulation. On the other hand, the "no-mixing hypothesis" is a rather constraining one, especially given the fact that there is evidence (MacAyeal, 1984) of efficient tidal mixing near grounding lines. A double-diffusion process within the pores of subglacial sediments, in areas sheltered from the Deep Thermohaline Convection, is therefore worth considering. In these areas, at some distance upstream from the actual decoupling of the glacier from its bed, sea water seeping through the sediments will come into contact with continental meltwaters (Fig. 2). Because the freezing point of sea water is lower than that of continental meltwater, heat diffusion will occur. Heat will diffuse through both liquid and solid fractions from upstream to sea water. On the other hand, the salinity of sea water being higher than that of continental meltwater, salts will diffuse from the sea-water-saturated sediment into the meltwaterfilled subglacial sediment. Salts can diffuse only through liquid, unlike heat. Thermal diffusivity is also an order of magnitude higher than salt diffusion. The meltwater-filled sediment loses heat more rapidly than it gains salt, and freezing occurs, welding the sediments to the bottom of the ice. Since this mechanism occurs within the subglacial sediments, rapid mixing between continental meltwater and sea water is precluded.
If the extended definition of the grounding line is considered, freezing can occur at different places, depending on variable water fluxes. Also, if the ice makes contact with a protuberance of the substratum in this critical area, pressure melting and regelation is likely to take place.

Such a double-diffusion mechanism leading to freezing at the grounding line would explain not only incorporation of debris into the glacier sole but also preservation of debrisrich ice already present upstream in the basal zone.

Is there evidence that such a process really occurs? The isotopic composition of debris-rich ice sampled in the region of Terra Nova Bay gives information on this question.

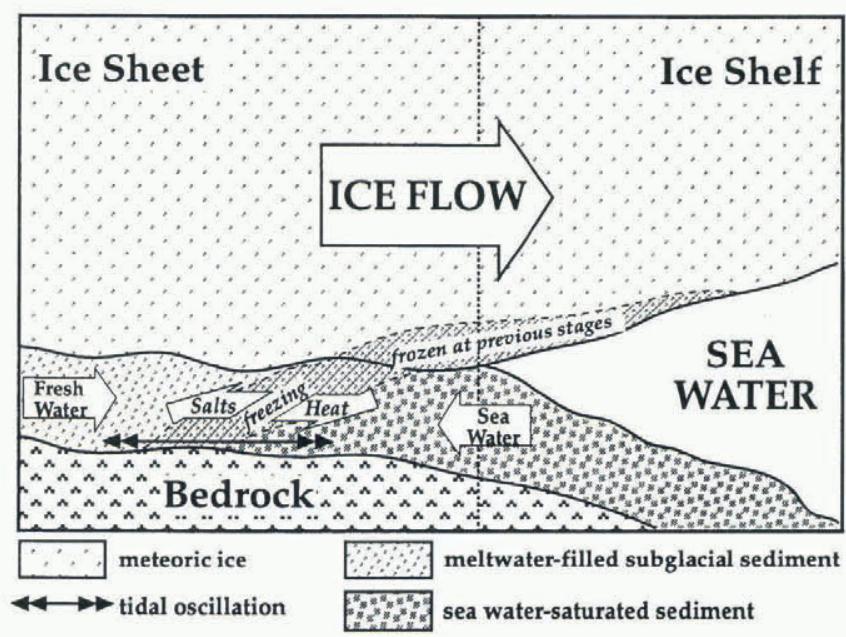

Fig. 2. Sketch of the suggested freezing mechanism by double diffusion at the grounding line.

\section{ISOTOPIC EVIDENGE OF THE DOUBLE-DIFFU- SION MEGHANISM}

Samples of bubbly glacier ice which reaches the sea in Terra Nova Bay (Fig. 3, inset), are aligned on a straight line in a $\delta \mathrm{D}-\delta^{18} \mathrm{O}$ diagram with equation $\delta \mathrm{D}=\left(7.91 \times \delta^{18} \mathrm{O}\right)+2.59$

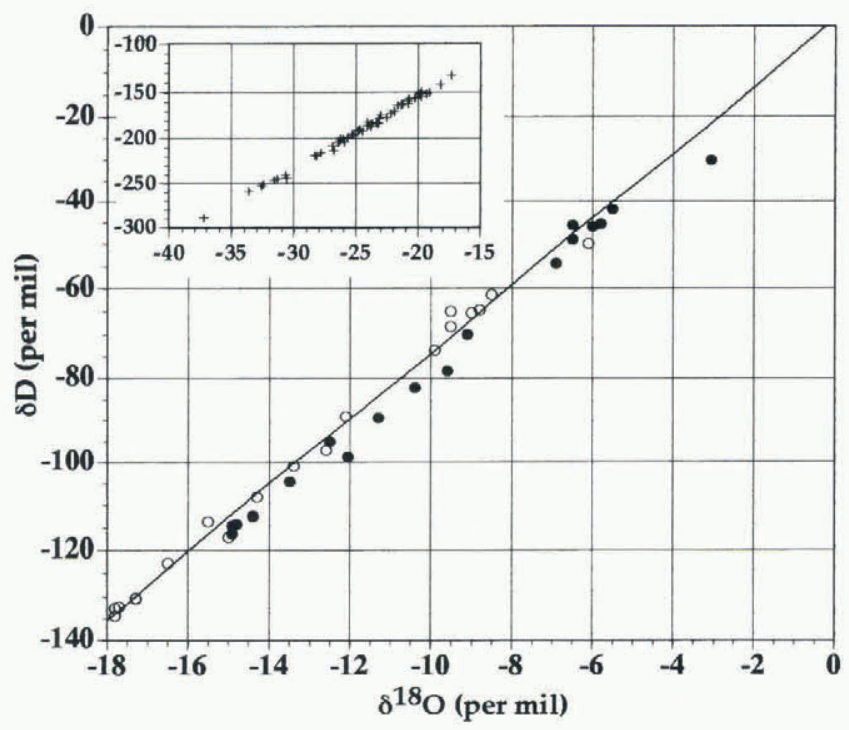

Fig. 3. $\delta D-\delta^{18} O$ diagram of the studied basal ice samples from Terra Nova Bay. Black circles: ice samples; open circles: initial water samples computed from $\delta$ values of ice samples and equilibrium fractionation coefficients. The straight line represents the best-fit line for the waters. Inset shows the $\delta D-\delta^{18} O$ diagram of glacier ice samples from the area. 
(correlation coefficient $0.997 ; 55$ samples). The $\delta$ values are more negative than $-17 \%$ in $\delta^{18} \mathrm{O}$ and $-130 \%$ in $\delta \mathrm{D}$. The straight line which can be considered as a local Meteoric Water Line or precipitation line goes close to Standard Mean Ocean Water. The $\delta$ values of the meltwaters from glacier ice will have the same isotopic composition since there is no fractionation on glacier ice melting.

By contrast, the debris-rich ice layers, thought to have been formed near the grounding line, from the western moraine ridge of Hells Gate Ice Shelf and from the site studied in Campbell Glacier Ice Tongue (Souchez and others, 1995) have $\delta$ values of $-15 \%$ to $-3 \%$ in $\delta^{18} \mathrm{O}$, and $-120 \%$ to $-30 \%$ in $\delta$ D. Detailed sampling locations at both sites are shown in Figure 1. A thorough description of the samples collected at Campbell Glacier Ice Tongue is given in Souchez and others (1995). The samples from Hells Gate Ice Shelf are from three shallow $(2 \mathrm{~m})$ ice cores drilled below the surficial dirt layers of two major dirt-ice cones located on the western moraine (Fig. 1). The textures of the cores were similar to those described for ice type 2 at Campbell Glacier, showing interlayering of debris layers with bubbly- and clear-ice layers at centimetric to decimetric scales. The bubbly-ice layers show typical meteoric-ice values, and the clear-ice/dirt-ice values are in the range $-3.07 \%$ to $-12.50 \%$ in $\delta^{18} \mathrm{O}$ and $-30.03 \%$ to $-98.90 \%$ in $\delta \mathrm{D}$. Samples from all cores are well aligned in a $\delta \mathrm{D}-\delta^{18} \mathrm{O}$ diagram on a straight line (Fig. 3), the equation for which is $\delta \mathrm{D}=\left(7.71 \times \delta^{18} \mathrm{O}\right)-1.15$ (correlation coefficient: $0.993 ; 18$ samples).

Progressive freezing downwards in a water mass or in a subglacial sediment produced, for example, by ice-thickness variations cannot explain this last distribution. Indeed, the observed slope is steeper than a freezing slope would be, and the ranges of $\delta$ values are such that near-complete freezing of the reservoir (99\%) would be required to understand the most negative $\delta$ values (Souchez and Jouzel, 1984). Ice intrusion of a subglacial sediment by pressure-induced regelation past grains is also precluded since the isotopic signature of such a process would have been different (Iverson and Souchez, 1996). On the other hand, pressure melting and regelation do not significantly modify the isotopic properties of the ice submitted to this process (Souchez and others, 1988).

If glacier-ice meltwater within the subglacial sediment enters into contact with sea water at the grounding line, diffusion will occur. Like salts, heavy isotopes of oxygen and hydrogen will diffuse from sea water, where they are less impoverished, to continental meltwater, where they are more depleted. Diffusion coefficients of stable isotopes and of salts in liquid water have the same order of magnitude, so that the double-diffusion mechanism described above also leads to isotopic diffusion. Therefore, the isotopic composition of the debris-rich ice layers formed by freezing will be dependent on the magnitude of the diffusion process prior to freezing. Isotopic composition is likely to be a better indicator of the process than the salt content since the different isotopes are within the lattice of the ice formed and only subjected, on very long time-scales, to solid-state diffusion.

From the isotopic composition of the ice layer formed, it is possible to reconstruct that of the initial water. Freezing at the subglacial site near the grounding line is most probably very slow, so that equilibrium fractionation can be considered. Therefore, taking into account the equilibrium fractionation coefficients for deuterium and oxygen-18 and the respective $\delta$ values of the ice, it is possible to compute the isotopic composition of the water which was later partially frozen. The best-fit line for the waters (Fig. 3) has the following equation: $\delta \mathrm{D}=\left(7.63 \times \delta^{18} \mathrm{O}\right)+1.9(r=0.993)$. This line goes close to points representing $\delta$ values of sea water in the area and $\delta$ values of meltwaters from glacier ice.

Isotopic diffusion within the water-filled subglacial sediment submitted to freezing by a double-diffusion mechanism seems thus to be the process explaining the peculiar distribution in the $\delta \mathrm{D}-\delta^{18} \mathrm{O}$ diagram.

\section{IMPLICATIONS}

Field observations from the present Interglacial indicate prevailing melting conditions at the base of the major Antarctic ice shelves (Jacobs and others, 1992). Models of the Deep Thermohaline Convection in sub-ice-shelf cavities have provided estimates of melt rates and growth rates (marine ice) under various areas of the Filchner-Ronne and Amery ice shelves (Bombosch and Jenkins, 1995; Jenkins and Bombosch, 1995; Grosfeld and others, 1997; Williams and others, 1998). Using a modeled mean bottom melting rate of $0.20 \mathrm{ma}^{-1}$ over $400 \mathrm{~km}$ in a downstream direction from the grounding line (Jenkins and Bombosch, 1995) and mean surface velocities of $500 \mathrm{~m} \mathrm{a}^{-1}$ (Jenkins and others, 1994), the bottom $160 \mathrm{~m}$ of the Ronne Ice Shelf will be lost before marine-ice accretion begins. Considering that observed basal debris-rich sequences at the bottom of ice tongues at the grounding lines do not exceed a few tens of meters, it is not surprising to find meteoric/marine ice interfaces devoid of significant sediment loads. During the glacial stages, however, the Antarctic ice sheet must have partly or fully refilled the sub-ice-shelf cavities and submarine trenches carved during the previous stages, thereby strongly inhibiting the Deep Thermohaline Convection. Therefore, conditions for freezing by a double-diffusion effect, i.e. conditions for preservation of basal debris to the frontal zone in contact with the ocean, would have been more prevalent than today. To what extent this mechanism will allow transport of basal sediments through iceberg drifts off the continental shelves is still conjectural. Recent work in the Prydz Bay area (Domack and Harris, 1998) shows that the grounding line did not make it to the continental shelf edge during the LGM. However, the situation may have been somewhat different in the Northern Hemisphere or for previous glacial stages in Antarctica. The present work points to the need to include grounding-line adfreezing processes in the development of the general picture, in order to fully understand typical events of sediment export to the Deep Sea, like the "Heinrich events" in the North Atlantic. The grounding line is indeed a spot of compelled passage for subglacial debris on its way to the ocean.

\section{ACKNOWLEDGEMENTS}

The authors would like to acknowledge the help received from the Italian Antarctic Program which made possible the ice sampling in Terra Nova Bay. This paper is a contribution to the Belgian Antarctic Program (Science Policy Office). J.-L. Tison is Research Associate at the Fond National de la Recherche Scientifique. 


\section{REFERENCES}

Bombosch, A. and A. Jenkins. 1995. Modeling the formation and deposition of frazil ice beneath Filchner-Ronne Ice Shelf. 7. Geophys. Res., 100(C4), 6983-6992.

Dayton, P. K., G. A. Robilliard and A. L. DeVries. 1969. Anchor ice formation in McMurdo Sound, Antarctica, and its biological effects. Science, $163(3864), 273-274$.

Domack, E.W. and P.T. Harris. 1998. A new depositional model for ice shelves, based upon sediment cores from the Ross Sea and Mac. Robertson shelf, Antarctica. Ann. Glaciol., 27 (see paper in this volume).

Grosfeld, K., R. Gerdes and J. Determann. 1997. Thermohaline circulation and interaction between ice shelf cavities and the adjacent open ocean. 7. Geophys. Res., 102 (C7), 15,595-15,610.

Iverson, N. and R. Souchez. 1996. Isotopic signature of debris-rich ice formed by regelation into a subglacial sediment bed. Geophys. Res. Lett., $23(10), 1151-1154$.

Jacobs, S.S., H. H. Hellmer, C. S. M. Doake, A. Jenkins and R. M. Frolich. 1992. Melting of ice shelves and the mass balance of Antarctica. $\mathcal{F}$. Glaciol., 38(130), 375-387.

Jenkins, A. and A. Bombosch. 1995. Modelling the effects of frazil ice crystals on the dynamics and thermodynamics of ice shelf water plumes. $\mathcal{F}$. Geophys. Res., 100 (C4), 6967-6981.

Jenkins, A., D. Vaughan and C. Doake. 1994. Numerical modelling of Filchner-Ronne Ice Shelf. In Oerter, H., ed. Fïlchner-Ronne Ice Shelf Programme. Report 8. Bremerhaven, Alfred Wegener Institute for Polar and Marine Research, 36-38.

Lewis, E. L. and R. G. Perkin. 1986. Ice pumps and their rates. F. Geophys. Res., $91(\mathrm{C} 10), 11,756-11,762$.
MacAyeal, D. R. 1984. Thermohaline circulation below the Ross Ice Shelf: a consequence of tidally induced vertical mixing and basal melting. 7 . Geophys. Res., 89(Cl), 597-606.

Oerter, H. and 6 others. 1992. Evidence for basal marine ice in the FilchnerRonne Ice Shelf. Nature, 358(6385), 399-401.

Powell, R. D., M. Dawber, J. N. McInnes and A. R. Pyne. 1996. Observations of the grounding-line area at a floating glacier terminus. Ann. Glaciol., 22, 217-223.

Souchez, R. A. and J. Jouzel. 1984. On the isotopic composition in $\delta \mathrm{D}$ and $\delta^{18} \mathrm{O}$ of water and ice during freezing. 7. Glaciol., 30(106), 369-372.

Souchez, R., R. Lorrain, J.-L. Tison and J. Jouzel. 1988. Co-isotopic signature of two mechanisms of basal-ice formation in Arctic outlet glaciers. Ann. Glaciol., 10, 163-166.

Souchez, R. and 6 others. 1995. Investigating processes of marine ice formation in a floating ice tongue by a high-resolution isotopic study. 7 . Geophys. Res., 100 (C4), 7019-7025.

Stocchino, C. 1991. Carta batimetrica, Mare di Ross - Baia Terra Nova. Second edition. Genova, Istituto Idrografico della Marina. (Scale 1:50000.)

Tison, J.-L., C. Barbante, A. Bondesan, R. Lorrain and A. Capra. In press. Ice shelf/ocean interactions at the front of Hells Gate Ice Shelf (Terra Nova Bay, Antarctica). Terra Antartica.

Williams, M.J. M., R. C. Warner and W. F. Budd. 1998. The effects of ocean warming on melting and ocean circulation under the Amery Ice Shelf, East Antarctica. Ann. Glaciol., 27 (see paper in this volume).

Zotikov, I. A. 1986. The thermophysics of glaciers (Teplofizika lednikovykh pokrovov). Dordrecht, D. Reidel Publishing Co.

Zotikov, I. A., V.S. Zagorodnov and J.V. Raikovsky. 1980. Core drilling through the Ross Ice Shelf (Antarctica) confirmed basal freezing. Science, 207(4438), 1463-1465. 